\title{
Preparing for the Worst? Household Food Stockpiling during the Second Wave of COVID-19 in Serbia
}

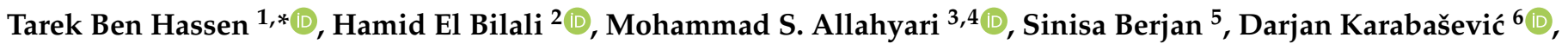 \\ Adriana Radosavac ${ }^{6}$, Goran Dašić ${ }^{7}$ and Ružica Đervida ${ }^{8}$
}

1 Program of Policy, Planning, and Development, Department of International Affairs, College of Arts and Sciences, Qatar University, Doha 2713, Qatar

2 International Centre for Advanced Mediterranean Agronomic Studies (CIHEAM-Bari), Via Ceglie 9, 70010 Valenzano, Italy; elbilali@iamb.it

3 Department of Agricultural Management, Rasht Branch, Islamic Azad University, Rasht 41476-54919, Iran; allahyari@iaurasht.ac.ir

4 Faculty of Economic and Management Sciences, North-West University, Mmabatho 2735, South Africa

5 Department of Agroeconomy and Rural Development, Faculty of Agriculture, University of East Sarajevo, 71126 Lukavac, Bosnia and Herzegovina; sinisa.berjan@ues.rs.ba

6 Faculty of Applied Management, Economics and Finance in Belgrade, University Business Academy in Novi Sad, 11000 Belgrade, Serbia; darjan.karabasevic@mef.edu.rs (D.K.); adriana.radosavac@mef.edu.rs (A.R.)

7 High School of Modern Business, Terazije 27, 11000 Belgrade, Serbia; goran.dasic@mbs.edu.rs

8 Faculty of Economics, Independent University of Banja Luka, NUBL, Veljka Mlađenovića 12e, 78000 Banja Luka, Bosnia and Herzegovina; ruzica.djervida@gmail.com

* Correspondence: thassen@qu.edu.qa

check for updates

Citation: Ben Hassen, T.; El Bilali, H.; Allahyari, M.S.; Berjan, S.;

Karabašević, D.; Radosavac, A.; Dašić, G.; Đervida, R. Preparing for the Worst? Household Food Stockpiling during the Second Wave of COVID-19 in Serbia. Sustainability 2021, 13, 11380. https://doi.org/ $10.3390 /$ su132011380

Academic Editor: Alessandra Durazzo

Received: 9 September 2021

Accepted: 6 October 2021

Published: 15 October 2021

Publisher's Note: MDPI stays neutral with regard to jurisdictional claims in published maps and institutional affiliations.

Copyright: (c) 2021 by the authors. Licensee MDPI, Basel, Switzerland. This article is an open access article distributed under the terms and conditions of the Creative Commons Attribution (CC BY) license (https:/ / creativecommons.org/licenses/by/ $4.0 /)$.
Abstract: Stockpiling and panic buying are significant components of crisis- and disaster-related consumption behaviors that have gained significant media coverage during the COVID-19 pandemic. This paper aims to analyze the features of stockpiling behavior during the second wave of COVID-19 in Serbia based on a structured online questionnaire. This study seeks to answer two questions. First, what factors triggered and affected stockpiling during the COVID-19 pandemic in Serbia? Second, how does stockpiling affect other food habits and diets? A total of 851 valid responses were received. The results highlight several features of the stockpiling behavior in Serbia. First, food stockpiling behavior is influenced by some sociodemographic variables such as gender and household composition. Second, stockpiling was fueled by several negative emotions such as fear, sadness, and depression. Third, the results confirm that stockpiling in Serbia was not triggered by supply shortages but rather by consumers' concerns of obtaining enough food and rising food prices. Finally, food stockpiling was associated with some positive changes such as eating out less (e.g., restaurants/cafeteria), eating more with their family members, and cooking more food. Analyzing and comprehending consumer food stockpiling patterns during the COVID-19 pandemic may offer policymakers imperative information for adjusting supply and response strategies during future crises.

Keywords: COVID-19; food consumption; food shopping; stockpiling; panic buying; Serbia; Balkans

\section{Introduction}

Consumers are subjected to systemic tension and stress during unstable circumstances such as wars, recessions, and natural catastrophes, resulting in the development, expansion, or modification of their behaviors [1,2]. The global COVID-19 pandemic is a stressful situation that has impacted the lifestyles and behaviors of the population suddenly and dramatically and will continue to have a broad direct and indirect influence [3]. Aside from the necessary enhanced focus on human health, concerns emerge about the pandemic's effect on food systems [4,5]. The COVID-19 pandemic and associated containment measures, including mobility restrictions, social distancing, and lockdowns, significantly prejudiced 
diet, daily food patterns, and general functioning of food systems [6,7]. The pandemic has also affected food shopping patterns: Stockpiling, online shopping, etc. [8-14].

Stockpiling and panic buying are significant components of crisis- and disaster-related consumption behaviors that gained significant media coverage during the COVID-19 pandemic [15]. Indeed, during a crisis, food becomes more fundamental to the consumers' lives, and panic purchasing is a normal human response to this stressful situation. Panic buying and stockpiling were shaped by several factors, including sociodemographic factors (e.g., culture, income, gender, and personality). This compulsive buying has several adverse effects, such as increasing food prices [16], food wastage, and stock out [17], and exacerbates overconsumption (cf. obesity) and unequal food access for some vulnerable groups (e.g., poor, elderly) [18-20]. Understanding the interaction between these several factors is crucial for enhancing the efficiency of crisis and disaster management, as well as human and economic resilience to current and potential crisis events. Understanding consumer food hoarding during the COVID-19 pandemic may also offer governments and policymakers vital information for readjusting inventories and reaction strategies [21].

As of 15 May 2021, Serbia has confirmed 705,185 confirmed cases of COVID-19 with 6646 deaths [22]. On 6 March 2020, Serbia confirmed its first case of COVID-19 [23]. As a result, on 15 March, a state of emergency was announced. Later, Serbia adopted several containment interventions to stop the virus: Nationwide lockdown, closure of non-essential businesses, shutting of schools and universities, remote work, etc. [24,25]. On 4 December 2020, the government implemented tighter COVID-19 measures in response to a rising number of infections. Nevertheless, these measures may have influenced food-related attitudes and behaviors, such as stockpiling [26]. According to the Serbian daily newspaper, Danas, Serbian consumers spent RSD 2 billion ( $€ 17$ million) more on food, drink, personal care, and housekeeping products in the three weeks ending 15 March 2020, compared to the same period in 2019. Sugar has emerged as one of the most sought-after items, followed by flour. The demand for frozen vegetables, canned tuna, eggs, pasta, frozen pastries, and edible oil also increased significantly [27]. Meanwhile, leading retail chains witnessed a 20\% increase in household consumption. Furthermore, during March 2020, the opening hours of supermarkets in Serbia were reduced to contain the spread of the SARS-CoV-2 virus [27]. Some previous research confirmed that the COVID-19 pandemic changed Serbia's food consumption, food shopping, and food $[26,28,29]$. However, not much is known about stockpiling behavior during the pandemic and the factors behind it. Moreover, the number of studies on stockpiling in the Balkan region is very limited. In fact, academic research on the effects of the COVID-19 pandemic on food systems and consumption habits has been geographically biased, with a concentration on Western and Southern Europe, North America, and China [13,30], while developing and Balkan countries in general, such as Serbia, have been overlooked. Further, since the COVID-19 pandemic is new and we do not know how long it will continue, there is a need for information and expertise to evaluate its effects on food behaviors and purchasing habits.

Accordingly, this study aims to fill this knowledge gap by analyzing the features of stockpiling behavior during the COVID-19 pandemic in Serbia. To our knowledge, it would be the first study of its kind in Serbia and the whole Balkan region. It seeks to answer two questions. First, what factors triggered and affected stockpiling during the COVID-19 pandemic in Serbia? Second, how does stockpiling affect other food habits and diets? Before presenting and discussing the research results, we describe the methodology.

\section{Panic Buying and Consumption Changes during Crises}

Panic buying is defined as a "phenomenon of a sudden increase in buying of one or more essential goods in excess of regular need provoked by adversity, usually a disaster or an outbreak resulting in an imbalance between supply and demand" [31] (p. 100). Unmatched panic buying dominated headlines during the early days of COVID-19 in 2020 in several countries just after confirming the first coronavirus cases. Panic buying (PB) has been reported recently with the COVID-19 pandemic, but it has existed for a long 
time. Panic buying is an unusual social behavior that has been seen in times of crisis and emergency [32]. External traumatic crises and events such as wars, recessions, natural catastrophes, and pandemics have caused the start, intensification, or changes in consumer habits as a means of coping with stress throughout history [1]. Disasters and crises clearly influence consumption behaviors [33]. Previous research has shown panic buying as a common reaction to environmental stresses or during stressful and uncertain times [34]. Indeed, several recent disasters demonstrated risk-averse consumer behavior [35]. These behavioral changes may have an impact on food intake attitudes and behaviors [36]. Panic buying and stockpiling are shaped by several factors.

Firstly, panic buying and stockpiling seem not triggered by supply shortages but rather by consumers' fears and anxieties of a potential shortage [37-39]. Additionally, food purchases are a behavioral response to stress and anxiety. During a stressful situation, perceived loss of control is unpleasant and motivates consumers to reclaim control over product procurement [40]. Stockpiling storable food products provides consumers with a feeling of control over the perilous situation generated by the crisis [41]. The lack of information about a health crisis influences dread of the unknown. It generates ambiguity, which leads individuals to ponder and envision various scenarios, causing anxiety [42]. Fear, rather than the epidemic itself, is often shown to influence purchasing behavior $[37,38,43]$. As the awareness of the virus and its possible severity was minimal at the outset of the outbreak, consumers all over the world, concerned about the long-term outlook, focused on impulse shopping and stockpiling storable food products (e.g., flour, pasta, canned items, rice, etc.) to mitigate the risk of future shortages [44,45].

Secondly, during a health disaster, people develop risk perceptions about the situation. According to Sheu and Kuo [46], panic buying before or after a catastrophe is a kind of self-protection behavior or deliberate action to reduce risk. Therefore, when there is a high perception of threat, an individual may stockpile food to reduce the danger of contracting the disease [47]. According to several studies, the potential threat of being infected with the virus affects consumer behavior when shopping for food. Thus, despite many protective measures and regulations applied by supermarkets (e.g., the installation of protective barriers at cash registers, frequent cleaning, the limitation of the maximum number of shoppers at one time, provision of masks, gloves, and disinfectants, etc.), for many consumers, shopping at a grocery store poses an evident danger $[48,49]$. Accordingly, some consumers stockpiled food to make fewer grocery-shopping visits and spend more on each trip to limit supermarket visits, thus reducing their potential risk of COVID-19 exposure [17]. Panic purchasing may, in this respect, be seen as a self-protection strategy to meet safety requirements [47].

Thirdly, panic buying is linked to perceived scarcity. Therefore, a product that is expected to become unavailable soon owing to a health issue may threaten or restrict personal freedom (i.e., prevented or reduced access to the product) [50]. This would thus trigger psychological responses and an urgent need to purchase and hoard behavior [51].

Fourthly, since consumers are members of a society, which could influence their decisions, panic buying is "contagious". According to Grasso [52], the fear of scarcity is self-fulfilling; the more individuals hoard, the more others are affected by the panic, and the quicker the food runs out. The media narrative could also aggravate this behavior. The dissemination of stories, pictures, and videos depicting individuals fighting in the aisles over products and shoppers lining up early in the morning to buy essential items on social media worsened this behavior [53]. Restaurants shut simultaneously, and people started to depend nearly entirely on groceries for their meals.

Finally, panic buying and stockpiling were shaped by several factors. Household preferences and attitudes and product types may be adjusted differently through time [54]. Overall, individuals in different age groups have responded differently to the health crisis [55]. However, these changes often depend on more extensive factors than individuals and are more tightly linked to local, national, and global decisions and policies [56]. For example, according to Prentice et al. [57], government measures related to COVID-19 are 
linked to panic buying in Australia. Panic buying began shortly after the first coronavirus cases were confirmed and rose significantly as the lockdown was expanded and social distancing measures were tightened.

This compulsive buying has several negative consequences, such as increasing food prices, food wastage [28], and stock out [17], and exacerbates overconsumption (cf. obesity) and unequal food access for some vulnerable groups (e.g., poor, elderly) [18-20]. Such behaviors alter the regular market by emptying shop shelves, inconveniencing other consumers, and sending panic and fear signals to society [58]. Likewise, panic buying increased household food waste generation, especially for perishable products, due to storage limitations, bad cooking habits, or overcooking $[17,59]$. Furthermore, panic buying disrupts supply chains [60]. Since the food distribution system is based on just-in-time, with fast-moving and low inventory levels, the sudden and unanticipated increase in demand resulted in short-run stock-outs, jeopardizing the stability of the food system $[33,61,62]$.

\section{Methods}

\subsection{Data Collection and Questionnaire Design}

The study was based on an online survey conducted in Serbia. The survey was administered in Serbian from 14 November until 10 December 2020. The survey was created using the Survey Monkey platform and circulated through social media (e.g., Twitter and Instagram). The study used the non-probability and the snowball-sampling technique $[63,64]$. Participants were asked to distribute the questionnaire to their friends and relatives. The study targets the broad adult population in Serbia (age > 18 years).

This study is part of the international research project "Consumer Agency, Food Consumption Behavior, and the Novel Coronavirus (COVID-19) Outbreak" sponsored by the Food Industry Research and Education Center (FIRE) at Western Michigan University [65]. The Western Michigan University Human Subjects Institutional Review Board (HSIRB) approved all research survey procedures. The Food Consumption Changes 2020 survey of West Michigan University [65] and the COVID-19 Survey of the United Nations System Standing Committee on Nutrition (UNSCN) [66] informed the questionnaire used in the online survey. The same survey, based on the same questionnaire, was conducted in several countries in the Middle East region, such as Qatar [67], Morocco [14], and Lebanon [13], and in Europe, such as Russia [68] and Bosnia [69].

The questionnaire comprised 24 different questions (multiple-choice, one option), split into three parts (Appendix A). The first section of the questionnaire included questions about the respondents' sociodemographic features, such as education level, gender, income, etc. The second part collected data on food purchase and consumption behavior during the COVID-19 pandemic, such as grocery shopping frequency-including panic buying and hoarding, diet, fears during grocery store visits, food waste, etc. Finally, the third section included questions about the positive (e.g., calm, optimistic, excited, etc.) and negative emotions (e.g., sad, bored, scared, etc.) experienced throughout the epidemic.

Two phases preceding the questionnaire distribution were completed. To first enhance the validity and reliability of the research, an expert panel performed a qualitative substance validity analysis. Based on the expert's opinion, irrelevant elements have been removed, and the rest have been amended to make them more effective and precise. Secondly, a pre-test with 25 participants to verify data precision and information was conducted before administration to improve the survey questions. As a consequence, 851 valid responses were received from which 351 respondents stockpiled food.

\subsection{Data Analysis}

SPSS (Statistical Package for Social Sciences) version 25.0 was used to analyze the survey results. Descriptive statistics (percentages and frequency distributions) were generated. Multiple answers were analyzed to deduce the percentages of answers and cases. Furthermore, the chi-square test was used to evaluate the association between variables since variables were examined on a nominal scale. In addition, logistic regression was 
applied to predict the dependent variable (stockpiling behavior) according to predictor variables. Non-parametric tests were used. Since there were only two groups, a binary logistic model was applied. The stepwise procedure was applied to estimate the model (seven steps were forwarded to find the most appropriate predictors for this study).

The probability of a 'yes' answer is $\mathrm{P}$, as shown in Equation (1) below. B is the constant regression term, and $B_{j i} s$ is the regression coefficient for $X_{j}$, which is a predictor variable with $j=1,2, \ldots, j$. The results section presents estimates $b$ for the beta and the value $\exp (B)$ to ease the interpretation. This value indicates a shift in odds when the relevant predictor variable rises by one unit and the dependent variable is 1 .

$$
\mathrm{P}=1 /\{1+\exp [-\mathrm{B}+\mathrm{B} 1 \times 1+\mathrm{B} 2 \mathrm{X} 2+\ldots+\mathrm{Bj} \mathrm{Xj}]\}
$$

\section{Results and Discussion}

\subsection{Sociodemographic Characteristics of the Study Participants}

The sociodemographic characteristics of the respondents are described in Table 1 . The findings indicate that $68 \%$ of the respondents are women, and $32.31 \%$ are married with children. Additionally, most of the respondents were middle-aged ( $44.77 \%$ were 25 to 45 years old), and $48 \%$ earned a higher income than other Serbian households. Overall, the sample was highly educated, as $78.26 \%$ possessed a university degree, master's, or Ph.D. In contrast, only $21.75 \%$ had a secondary school diploma or no qualifications. In terms of occupation status, of all the interviewees, $74.15 \%$ were working (full-time or part-time), $20.33 \%$ were students, and $9.82 \%$ were unemployed and searching for jobs (Table 1 ).

Table 1. Sociodemographic characteristics of the survey participants $(n=851)$.

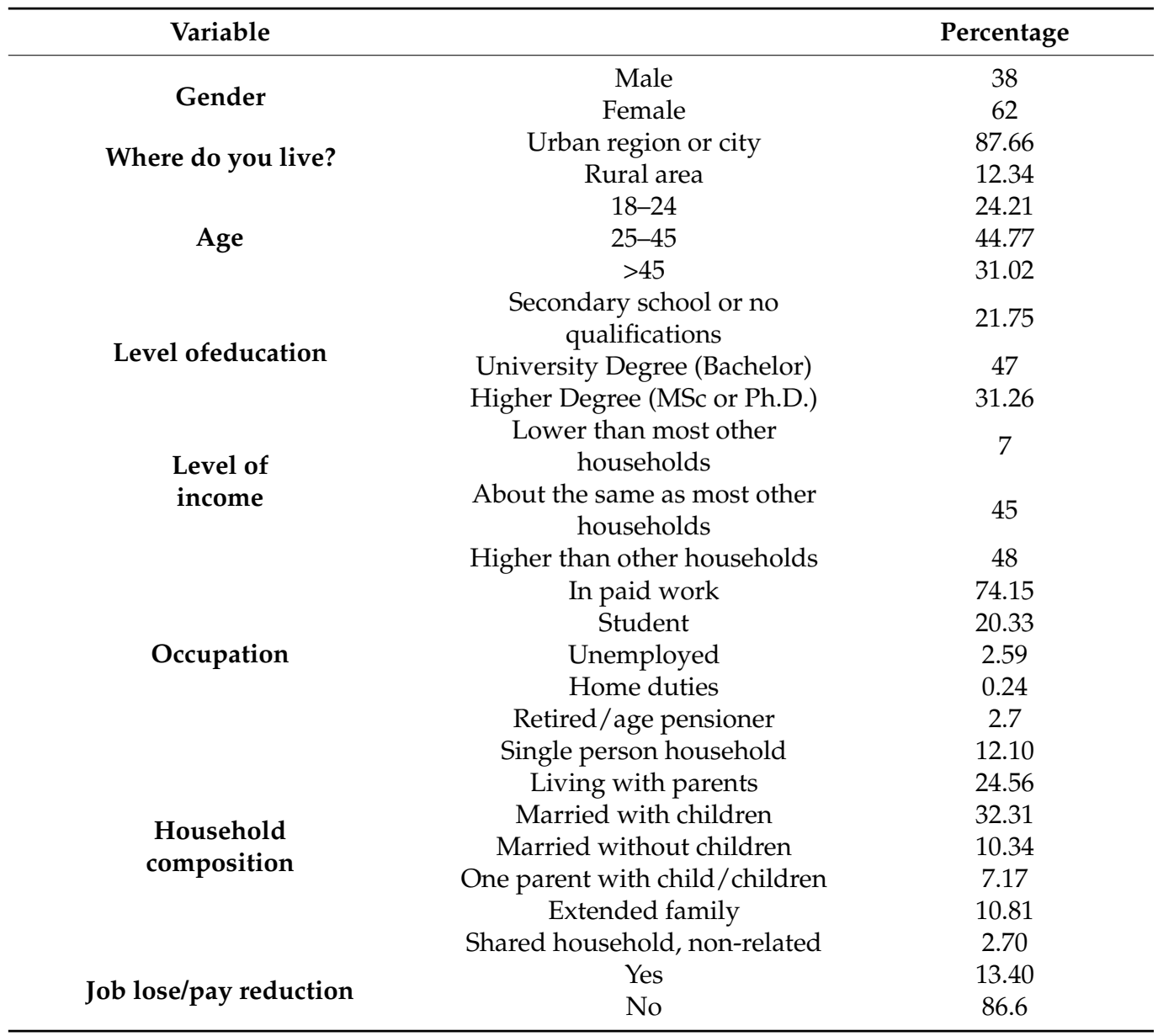




\subsection{Stockpiling Dynamics during the COVID-19 Pandemic}

The survey results highlight different, sometimes divergent, dynamics about food stockpiling behavior among Serbian households during the second wave of the COVID-19 pandemic.

Firstly, consumers who stockpiled food had a different shopping behavior. They made fewer grocery-shopping visits and spent more on each trip to limit supermarket visits. Indeed, $38.18 \%$ of the participants who stockpiled food made fewer grocery-shopping visits than usual compared to $26.6 \%$ for those who did not stockpile food. In addition, $40.74 \%$ of those who stockpiled food spent more than usual on each trip to limit supermarket visits, compared to $10.2 \%$ for those who did not stockpile food (Figure 1). These results suggest that many Serbians made recourse to panic buying as a kind of self-protection behavior [46] and a deliberate action to reduce the risk of contracting the disease [47] by reducing the number of trips to supermarkets and shops. Indeed, the survey shows that many Serbian consumers stockpiled food to make fewer visits to shops while spending more time on each visit/trip, thus reducing their perceived potential risk of COVID-19 exposure $[17,48,49,70]$.

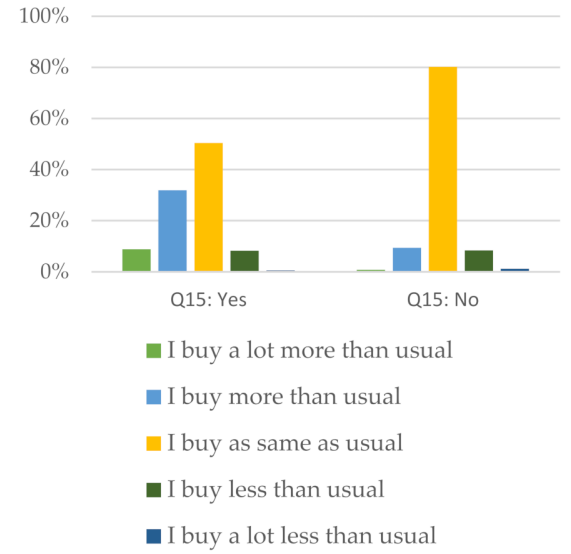

(a)

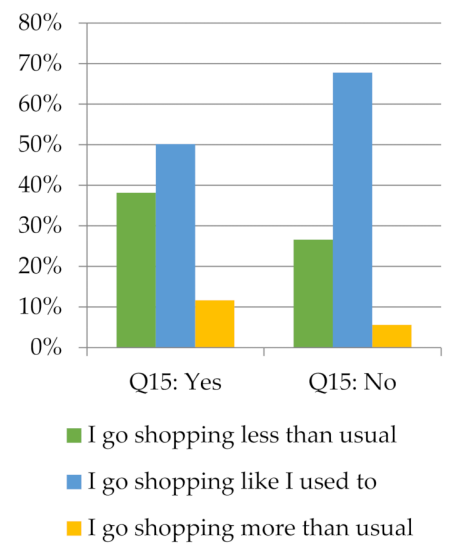

(b)

Figure 1. Shopping behavior changes (a) and food stockpiling (b) during the COVID-19 pandemic $(n=851)$. Yes: Stockpiling respondents; No: Non-stockpiling respondents.

Second, as indicated in Figure 2, stockpiling during the COVID-19 pandemic was fueled by negative emotions such as fear, sadness, and depression. Indeed, participants who stockpiled food felt more nervous, worried, and/or sad than those who did not.

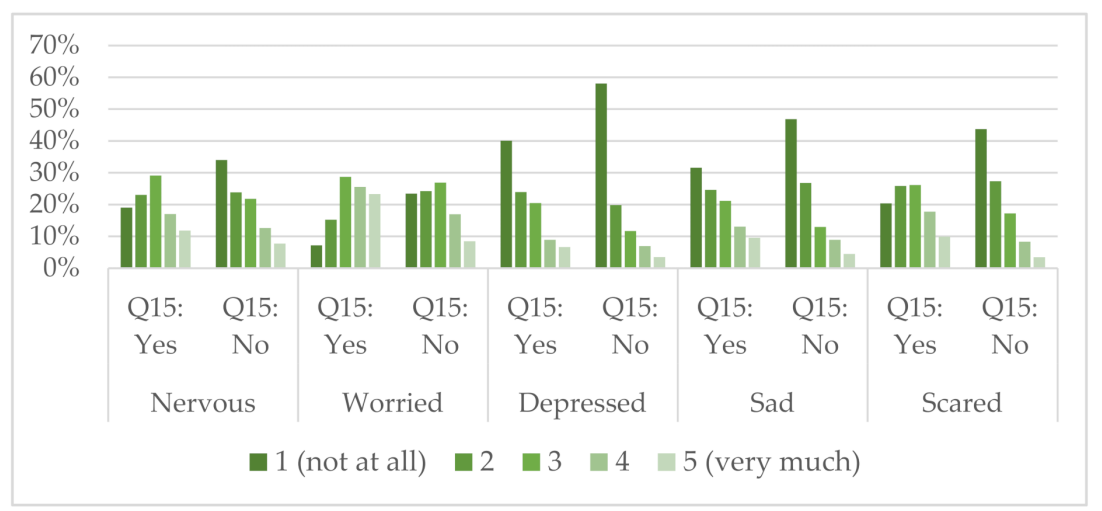

Figure 2. Stockpiling behavior and emotions during the COVID-19 pandemic $(n=851)$. Yes: Stockpiling respondents; No: Non-stockpiling respondents. 
Further, the results confirm that stockpiling is not triggered by supply shortages but rather by consumers' fears and concerns of a potential shortage. Indeed, $24.22 \%$ of the participants who stockpiled food were concerned about obtaining enough food compared to $5.6 \%$ for those who did not stockpile food. In addition, $31.62 \%$ of the participants who stockpiled food were concerned about food prices rising, compared to $19.06 \%$ for those who did not stockpile food (all by including levels 4 "very concerned" and 5 "extremely concerned") (Figure 3). As Hansman et al. [71] underlined, this behavior has some economic explanations. Indeed, a crisis often leads to higher predicted future prices, making the current price appear as a "deal" requiring stockpiling as the optimum behavior. These results align with those obtained by Tsao et al. [39] and Maghsoudi et al. [50], who argue that panic buying and stockpiling seem triggered by consumers' fears and anxieties of a potential, perceived shortage, rather than an accurate and effective food shortage. Therefore, feelings, emotions, and perceptions (that can be fueled by social media or even 'fake news') are essential determinants of panic buying. This clearly shows the importance of effective communication during crises and emergencies [42,43], such as the COVID-19 pandemic. Communication at the onset of crises is fundamental to prevent panic buying as this 'social' behavior seems quickly 'contagious' [52,53] and can degenerates in a short time if not managed in an effective and timely way. However, as for any government measure or intervention during the COVID-19 crisis [56,57], communication and awareness-raising campaigns should be well targeted in order to yield the expected results. Such campaigns should also highlight the many negative impacts of panic buying and stockpiling on agrifood markets and supply chains [17-20,33,58,60-62] and, consequently, food availability and accessibility for consumers themselves.

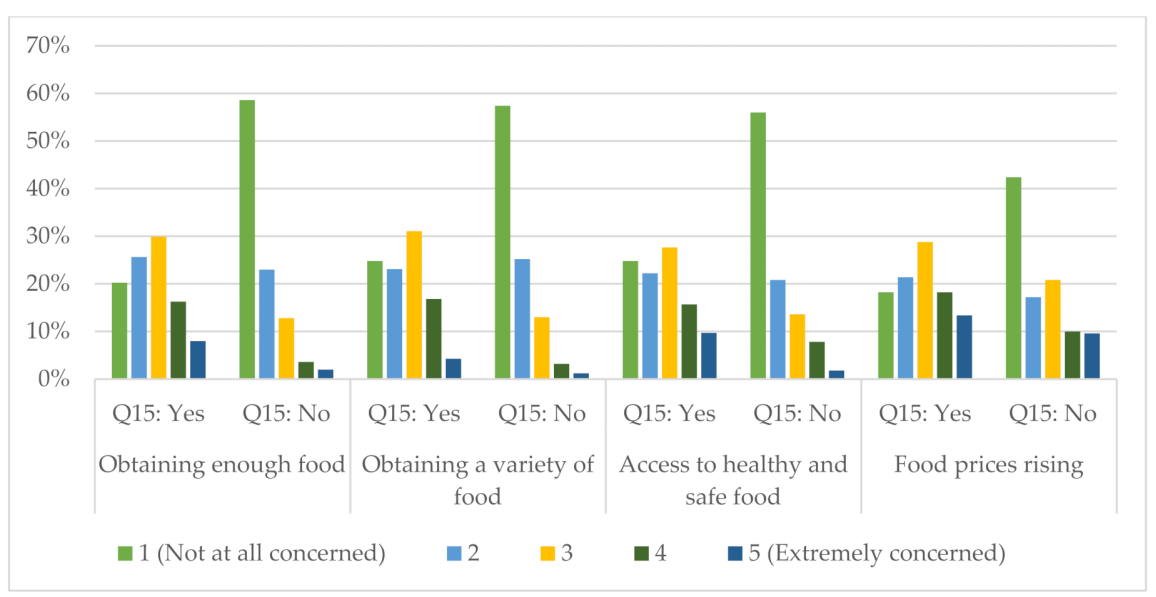

Figure 3. Concerns about some food-related issues during the pandemic. Yes: Stockpiling respondents; No: Non-stockpiling respondents. ${ }^{*}$ Scale: $1=$ not at all concerned; 2 = slightly concerned; 3 = concerned; 4 = very concerned; 5 = extremely concerned.

Third, the results confirm that stocking food products provides customers with a feeling of control over the perilous situation generated by the actual health crisis. Indeed, $35.9 \%$ of the participants who stockpiled food indicated that this behavior makes them feel more secure, $24.5 \%$ indicated that it comforts them, and 30.5\% indicated that it gives them a sense of control (all by including levels 4 and 5) (Figure 4). These results suggest that panic buying and stockpiling are behavioral responses to negative feelings and emotions such as stress, fear, and anxiety and a way for consumers to reclaim control over product procurement [40]. Indeed, stockpiling food provides consumers with a feeling of control [41]. 


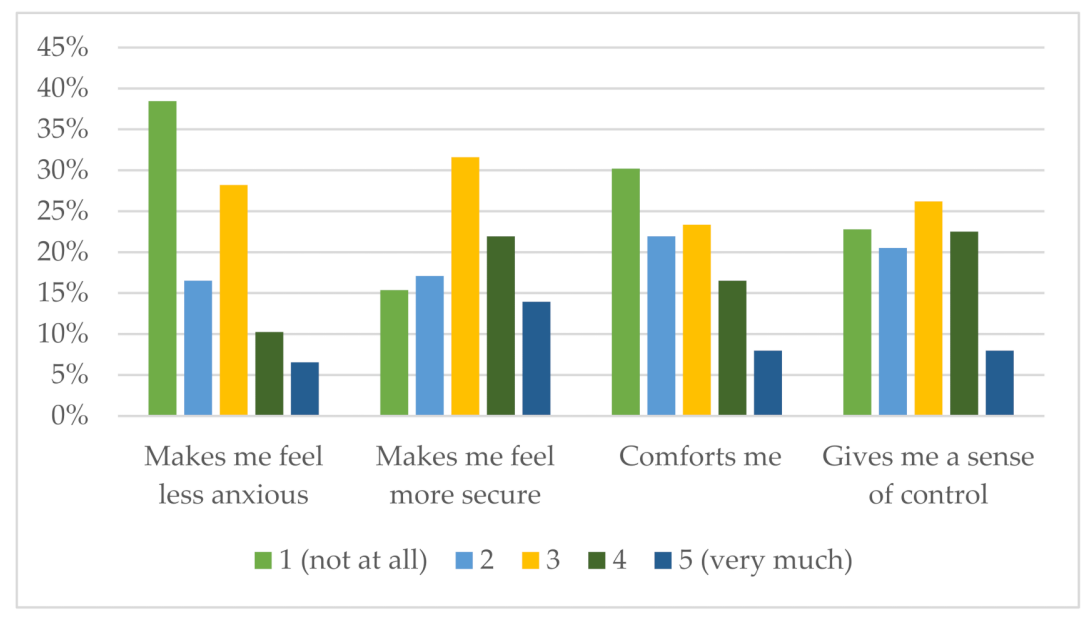

Figure 4. Effects of stocking up on feelings.

\subsection{Stockpiling and Food Activities during the COVID-19 Pandemic}

The behavior of the participants who stockpiled food was different compared to those who did not. Firstly, $40.74 \%$ of the respondents who stockpiled food ate more with their family members, $56.7 \%$ cooked more food, and $18 \%$ made more easy meals (e.g., instant foods, frozen foods, etc.) than usual, compared to $27.6 \%, 38.2 \%$, and $10.4 \%$ for those who did not stockpile food (all by counting "moderately more" and "much more" answer options).

Secondly, $63.25 \%$ of the respondents who stockpiled food ate less out (e.g., restaurants/cafeteria/fast food), and $28 \%$ ordered fewer take-away or fast-food meals with deliveries than usual, compared to $54.6 \%$ and $18.8 \%$ for those who did not stockpile food (all by counting "slightly less" and "much less" answer options). However, 31.05\% of the respondents who stockpiled food ate between meals (snacks) compared to $17.8 \%$ for those who did not stockpile food (all by counting "moderately more" and "much more" answer options) (Table 2).

Table 2. Stockpiling and food activities during the COVID-19 pandemic (percentage) $(n=851)$.

\begin{tabular}{|c|c|c|c|c|c|c|c|c|}
\hline Food Activity & Stockpiling & First Time & $\begin{array}{l}\text { Much } \\
\text { Less }\end{array}$ & $\begin{array}{l}\text { Slightly } \\
\text { Less }\end{array}$ & $\begin{array}{c}\text { About the } \\
\text { Same }\end{array}$ & $\begin{array}{l}\text { Moderately } \\
\text { More }\end{array}$ & $\begin{array}{l}\text { Much } \\
\text { More }\end{array}$ & Never \\
\hline \multirow{2}{*}{ Eating with family members } & Q15: Yes & 0.28 & 5.98 & 3.42 & 48.15 & 16.24 & 24.50 & 1.42 \\
\hline & Q15: No & 0.20 & 4.20 & 2.60 & 65.00 & 9.80 & 17.80 & 0.40 \\
\hline \multirow{2}{*}{ Cooking and preparing food } & Q15: Yes & 0.57 & 1.14 & 1.14 & 39.60 & 25.64 & 31.05 & 0.85 \\
\hline & Q15: No & 0.40 & 0.80 & 1.40 & 58.20 & 18.40 & 19.80 & 1.00 \\
\hline \multirow{2}{*}{$\begin{array}{l}\text { Eating out (e.g., } \\
\text { restaurants/cafeteria) }\end{array}$} & Q15: Yes & 0.57 & 49.29 & 13.96 & 17.66 & 2.85 & 0.85 & 14.81 \\
\hline & Q15: No & 0.00 & 38.00 & 16.60 & 30.80 & 2.80 & 1.00 & 10.80 \\
\hline \multirow{2}{*}{ Ordering take-away } & Q15: Yes & 0.28 & 18.23 & 9.69 & 28.49 & 16.52 & 5.70 & 21.08 \\
\hline & Q15: No & 0.00 & 13.00 & 5.80 & 42.40 & 10.60 & 4.40 & 23.80 \\
\hline \multirow{2}{*}{ Eating between meals } & Q15: Yes & 0.00 & 10.26 & 5.70 & 45.01 & 20.51 & 10.54 & 7.98 \\
\hline & Q15: No & 0.00 & 10.20 & 6.20 & 55.60 & 12.60 & 5.20 & 10.20 \\
\hline
\end{tabular}

Further, the Chi-square test result shows a meaningful association between stockpiling food and food waste behavior $\left(\chi^{2}=23.72, p<0.01\right)$. Thus, stockpiling food did not increase food waste. In fact, for $34.61 \%$ of the respondents who stockpiled food, their waste became less compared to $25.8 \%$ for those who did not stock food (by including "It has become much less" and "much less" answer options) (Figure 5). These results are in agreement with those obtained by other scholars [17,59], who argue that panic buying and consequent food stockpiling increased household food waste generation, especially for perishable, short shelf-life products (e.g., fruits, vegetables, etc.). The reasons behind such an increase may be related, among others, to cold storage limitations and bad conservation/preservation conditions. 


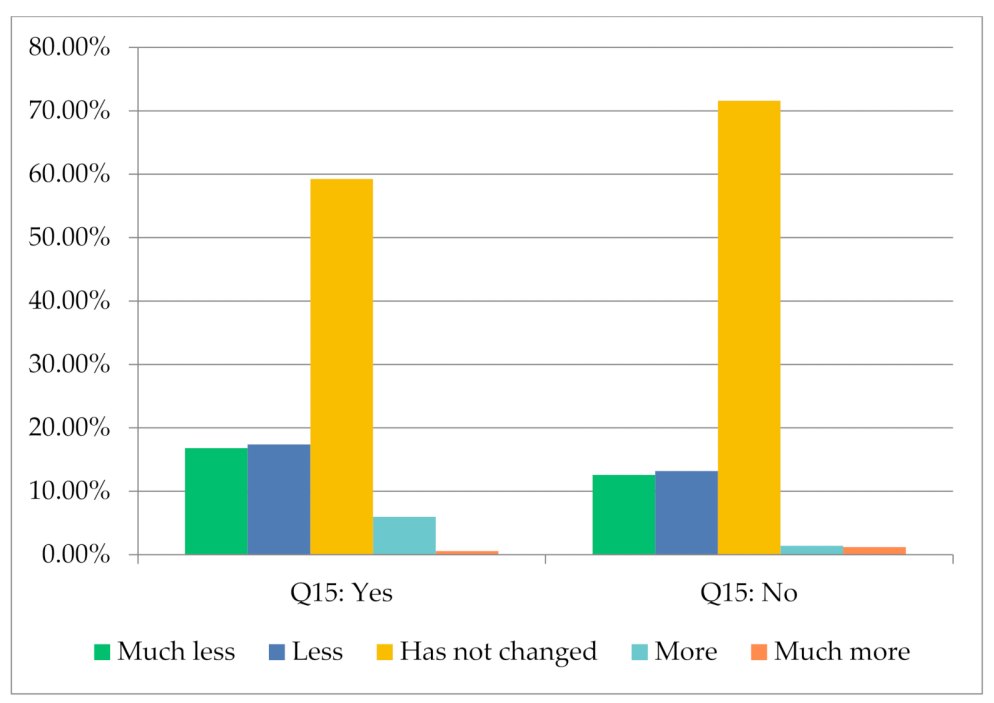

Figure 5. Food waste change and stockpiling during the COVID-19 pandemic $(n=851)$. Yes: Stockpiling respondents; No: Non-stockpiling respondents.

Accordingly, stockpiling food did not increase food waste in Serbia during the pandemic. In other words, the increased food purchases during the pandemic did not increase food waste. This may imply that, since the coronavirus outbreak, Serbian consumers have adopted a broad range of positive food management strategies, such as better food shopping planning, enhanced in-house food storage, and enhanced use of leftovers. This points to an encouraging shift toward more sustainable food consumption habits. Overall, household food waste in Serbia is low, as in most developing countries in the Balkan region [72-74]. However, there is no accurate information on how much food is wasted in Serbia. According to National Geographic Serbia [75], $35 \mathrm{~kg}$ of food is thrown away per capita per year. Djekic et al. [76] suggest that, annually, Serbian households discard 198,712 tons of food waste associated with 687,346 tons of $\mathrm{CO}_{2}$ emission. As has been observed in many countries, such as Italy [77], Russia [68], or Qatar [67], the COVID-19 pandemic has induced a positive behavioral shift in food waste in Serbia.

Furthermore, the logistic regression analysis results revealed that the overall predictive power of the model was $78.4 \%$, while the substantial Chi-square $(p<0.01)$ showed the strength of the model, and $78.4 \%$ of the respondents were grouped correctly. In logistic regression, the value of the $-2 \log$-likelihood statistic is widely used to measure the goodness of fit of the model ( $-2 \mathrm{LL}=772.26)$. This statistic behaves like Chi-square, and when the estimated logit model fits with data well, its value decreases. The decrease is equal to the decrease in the improved Chi-square and the Chi-square model. The decline from 292,73 to 4.14 in the value of this figure showed the fit of the model. According to Nagelkerke R2, the variables included in the model accounted for $47.1 \%$ of the variation in the calculated variance. As a result, the estimated logit model could estimate a modest proportion of the dependent variable's values using the variables in the equation (e.g., obtaining enough food, food prices rising, food spreading COVID-19, etc.) (Table 3).

According to the $b$ coefficients, seven influencing factors out of sixteen entered the equation that may substantially impact the willingness to stockpile food. There was a significant positive relationship between several variables such as obtaining enough food, "stocking up on items makes me feel more secure", "stocking up on items gives me a sense of control", etc., and the dependent variable, willingness toward stockpiling behavior. By contrast, there was a significant negative relationship between the dependent variable "willing toward stockpiling behavior" and the variables "food prices rising" and "stocking up on items comforts me". $\operatorname{Exp}(B)$ values are the odds ratios for the predictors. They are the exponentiation of the coefficients. According to $\operatorname{Exp}(\mathrm{B})$ values, the highest effect was that stocking up on items makes me feel more secure (2.295), stocking up on items gives 
me a sense of control (1.907), and obtaining enough food (1.502) (Table 3). These results confirm that stockpiling is not triggered by supply shortages but rather by consumers' fears and concerns of a potential shortage.

Table 3. Logistic regression analysis.

\begin{tabular}{|c|c|c|c|c|c|c|}
\hline & & B & S.E. & Wald & $p$-Value & $\operatorname{Exp}(B)$ \\
\hline \multirow{8}{*}{ Step 7 * } & Obtaining enough food & 0.407 & 0.099 & 16.82 & 0.000 & 1.502 \\
\hline & Food prices rising & -0.160 & 0.080 & 4.03 & 0.045 & 0.852 \\
\hline & Food spreading COVID-19 & 0.185 & 0.073 & 6.34 & 0.012 & 1.203 \\
\hline & Cooking and preparing food & 0.236 & 0.097 & 5.89 & 0.015 & 1.266 \\
\hline & Stocking up makes me feel more secure & 0.831 & 0.126 & 43.71 & 0.000 & 2.295 \\
\hline & Stocking up comforts me & -0.446 & 0.166 & 7.23 & 0.007 & 0.640 \\
\hline & Stocking up gives me a sense of control & 0.645 & 0.131 & 24.24 & 0.000 & 1.907 \\
\hline & Constant & -4.801 & 0.540 & 79.01 & 0.000 & 0.008 \\
\hline
\end{tabular}

${ }^{*}$ Overall percentage of classification $=78.4 \%,-2$ Log likelihood $=772.26$, Nagelkerke R Square $=0.471$.

\subsection{Effects of Sociodemographic Characteristics on the Stockpiling Behavior}

During the COVID-19 pandemic in Serbia, food stockpiling was influenced by several individual and socio-economic variables such as gender, household composition, etc.

Firstly, the results reveal that women stockpiled more food than men. Indeed, only $36.72 \%$ of men stocked up food compared to $44 \%$ of women. In general, shopping for food and ensuring that enough food is available for the family are women's responsibilities. As indicated by Georgiadou et al. [78], in several countries, during the pandemic, women were less inclined to continue shopping as usual. Additionally, only $37 \%$ of the 18-24-year-old participants stocked up on food compared to $47.77 \%$ for the $45-54$-year-old participants (Table 4).

Table 4. Effects of socio-demographics on the stockpiling behavior (percentage) $(n=851)$.

\begin{tabular}{|c|c|c|c|c|}
\hline Variable & & $\begin{array}{c}\text { Total } \\
\text { (Percentage) }\end{array}$ & $\begin{array}{l}\text { Yes: Stockpiling } \\
\text { Respondents } \\
\text { (Percentage of the } \\
\text { Total) }\end{array}$ & $\begin{array}{c}\text { No: } \\
\text { Non-Stockpiling } \\
\text { Respondents } \\
\text { (Percentage of the Total) }\end{array}$ \\
\hline \multirow{2}{*}{ Gender } & Male & 38 & 34 & 41 \\
\hline & Female & 62 & 66 & 59 \\
\hline \multirow{3}{*}{ Where do you live? } & Urban region or city & 87.66 & 88 & 87.40 \\
\hline & Rural area & 12.34 & 12 & 12.6 \\
\hline & $18-24$ & 24.21 & 21.94 & 25.80 \\
\hline \multirow[t]{2}{*}{ Age } & $25-45$ & 44.77 & 45.87 & 44 \\
\hline & $>45$ & 31.02 & 32.2 & 30.20 \\
\hline \multirow{3}{*}{$\begin{array}{l}\text { Level of } \\
\text { education }\end{array}$} & $\begin{array}{c}\text { Secondary school or no } \\
\text { qualifications }\end{array}$ & 21.75 & 18.8 & 23.8 \\
\hline & University Degree (Bachelor) & 47 & 44.45 & 48.80 \\
\hline & Higher Degree (MSc or Ph.D.) & 31.26 & 36.75 & 27.40 \\
\hline \multirow{2}{*}{$\begin{array}{l}\text { Level of } \\
\text { income }\end{array}$} & $\begin{array}{l}\text { Lower than most other } \\
\text { households }\end{array}$ & 7 & 6.27 & 7.40 \\
\hline & $\begin{array}{c}\text { About the same as most other } \\
\text { households }\end{array}$ & 45 & 44.73 & 45 \\
\hline \multirow{7}{*}{ Occupation } & Higher than other households & 48 & 49.01 & 47.60 \\
\hline & In paid work & 74.15 & 77.78 & 71.60 \\
\hline & Student & 20.33 & 17.38 & 22.40 \\
\hline & Unemployed & 2.59 & 2.56 & 2.60 \\
\hline & Home duties & 0.24 & 0 & 0.4 \\
\hline & Retired/age pensioner & 2.7 & 2.28 & 3 \\
\hline & Single person household & 12.10 & 11.68 & 12.40 \\
\hline \multirow{5}{*}{$\begin{array}{l}\text { Household } \\
\text { composition }\end{array}$} & Living with parents & 24.56 & 19.37 & 28.20 \\
\hline & Married with children & 32.31 & 35.61 & 30 \\
\hline & Married without children & 10.34 & 11.68 & 9.40 \\
\hline & One parent with child/children & 7.17 & 7.69 & 6.80 \\
\hline & Extended family & 10.81 & 11.11 & 10.60 \\
\hline \multirow{3}{*}{ Job lose/pay reduction } & Shared household, non-related & 2.70 & 2.85 & 2.60 \\
\hline & Yes & 13.40 & 13.39 & 13.40 \\
\hline & No & 86.6 & 86.61 & 86.60 \\
\hline
\end{tabular}


Secondly, household composition influenced stockpiling behavior. For instance, respondents who were married with children $(45.45 \%)$ or without children $(46.6 \%)$ stockpiled more food than those living with their parents (32.53\%). Meanwhile, some other sociodemographic features, e.g., income and place of residence, did not affect food stockpiling.

The results confirm that the effects of the COVID-19 epidemic on a consumer's mindset vary according to several sociodemographic characteristics such as gender, age, and household composition. For instance, larger households, especially families with children, tend to stockpile more food than smaller ones. Indeed, the consequences of COVID-19 on the economy, health, well-being, and nutrition varied not only from a household to another but also among individuals [79]. Overall, COVID-19's effect on consumer behavior has been shaped by many factors, including sociodemographic and household preferences and attitudes [80]. In general, sociodemographic characteristics are essential in predicting consumer purchasing behavior [81] and remain prominent classification variables in marketers' segmentation tactics [82].

\section{Conclusions}

In this paper, we investigate the features of stockpiling behavior during the COVID-19 pandemic in Serbia. As observed in several countries, stockpiling behavior in Serbia had been shaped by several factors, including socio-demographics, fear of the virus, etc. Firstly, the results indicate that stockpiling food during the COVID-19 pandemic in Serbia was influenced by various individual and socio-economic variables such as gender, family, etc. Secondly, as expected, stockpiling food was triggered by several factors. For instance, consumers who stockpiled food had a different shopping behavior. They made fewer grocery-shopping visits and spent more on each trip to limit supermarket visits, thereby controlling their perceived risk of exposure to COVID-19. Thirdly, food stockpiling has several consequences. For instance, those who stockpiled food ate out less and ordered less restaurant food and coffee. Furthermore, they cooked more than usual and ate more with family members.

\section{Practical Applications and Limitations}

While there have been some promising findings of the effectiveness of the COVID-19 vaccine, the pandemic is far from over, and some countries still face significant disease pressure, but even those who currently control the virus fear more waves. The risk of new infections and waves may result in new lockdowns or new strict measures, and panic buying will likely happen again, leading to further disruption of food systems. For example, cases of panic buying were reported in many countries at the beginning of the second wave in November 2020. More recently, during May 2021, in Taiwan, new COVID-19 restrictions triggered panic buying of food items such as instant noodles [83]. This implies that continued efforts are required to adapt to and mitigate the pandemic's long-term effects. Hoarding of staples has long worried policymakers due to shortages [71]. This and other future research will serve as a foundation for organizational and government preparation for future shocks and pandemic outbreaks. In addition, the paper results indicate that increasing consumer awareness via multi-channel information and communication campaigns, as well as maintaining a consistent supply of agri-food markets, is critical to prevent stockpiling during crises such as pandemics. The study's findings are also useful in developing evidence-based strategies for the post-pandemic recovery period in Serbia and the Balkan area as a whole.

Finally, the major limitation of this study is sample bias, which is a frequent issue in computer-assisted web interviewing (CAWI), which is often employed in surveys [84-87]. The research participants were unpaid volunteers who were chosen at random (cf. selfselection of the sample). They took the survey because the topic piqued their interest. For example, women and educated people were overrepresented in our sample. Consequently, not every subgroup is represented proportionately. Indeed, web-illiterate individuals, elderly, poor households, and informal workers are excluded from online surveys. With 
this bias, generalizing the survey findings to the whole Serbian population is challenging. However, due to the COVID-19 epidemic, online surveys may be used to gather data remotely, which is a significant advantage when social distance is required since face-toface interviews are complicated and risky.

Author Contributions: Conceptualization, T.B.H. and H.E.B.; methodology, T.B.H., H.E.B., and M.S.A.; software, M.S.A.; validation, M.S.A.; formal analysis, T.B.H., H.E.B., M.S.A., and S.B.; investigation, D.K., A.R., G.D., and R.Đ.; data curation, M.S.A.; writing—original draft preparation, T.B.H. and H.E.B.; writing-review and editing, T.B.H., H.E.B., and M.S.A.; project administration, T.B.H. and H.E.B.; funding acquisition, T.B.H. All authors have read and agreed to the published version of the manuscript.

Funding: This research did not receive any specific grant from funding agencies in the public, commercial, or not-for-profit sectors.

Institutional Review Board Statement: Not applicable.

Informed Consent Statement: Not applicable.

Data Availability Statement: The data used during the present investigation are available upon request to the corresponding author.

Conflicts of Interest: The authors declare no conflict of interest.

\section{Appendix A Questionnaire: Respondent's Profile}

1. Gender

- Male

- Female

2. Where do you live?

- Urban region or city

- Rural area or village

3. Age

- $18-24$

- 25-34

- $35-44$

- $45-54$

- 55 and over

4. Level of education

- No formal schooling

- Primary school

- Preparatory level

- Secondary school

- University degree

- $\quad H i g h e r$ degree (MSc or Ph.D.)

5. How would you describe your household income compared to other households in your country?

- Much lower than most other households

- Slightly lower than most other households

- About the same as most other households

- Slightly higher than other households

- Much higher than other households

6. Occupation

- In paid work (full time or part time)

- $\quad$ Student 
- Unemployed and looking for work

- Home duties

- $\quad$ Retired/Age pensioner

7. What is your household composition?

- $\quad$ Single person

- Living with parents

- Married with children

- Married without children

- Extended family: grandparents, children, grandchildren, etc.

- Shared household, non-related

8. How many people are currently living in your home?

- Children 18 years or younger

- Adults (including yourself)

- Total (including yourself)

9. Have you lost your job or had any pay reduction in your salary due to COVID-19?

- Yes

- No

\section{Food Buying and Consumption Behavior}

10. Below is a list of food-related behaviors. Please indicate how that behavior has changed for you as a result of the coronavirus (COVID-19) becoming serious in your country.

\begin{tabular}{|c|c|c|c|c|c|c|c|}
\hline & $\begin{array}{l}\text { First } \\
\text { Time }\end{array}$ & $\begin{array}{l}\text { Much } \\
\text { Less }\end{array}$ & $\begin{array}{l}\text { Slightly } \\
\text { Less }\end{array}$ & $\begin{array}{l}\text { About the } \\
\text { Same }\end{array}$ & $\begin{array}{l}\text { Slightly } \\
\text { More }\end{array}$ & $\begin{array}{l}\text { Much } \\
\text { More }\end{array}$ & Never \\
\hline \multicolumn{8}{|l|}{$\begin{array}{c}\text { Buying local food } \\
\text { (produced in your } \\
\text { country) }\end{array}$} \\
\hline \multicolumn{8}{|l|}{$\begin{array}{l}\text { Ordering groceries } \\
\text { online }\end{array}$} \\
\hline \multicolumn{8}{|l|}{$\begin{array}{l}\text { Buying food in } \\
\text { person from a } \\
\text { large supermarket } \\
\text { (example } \\
\text { Carrefour) }\end{array}$} \\
\hline \multicolumn{8}{|l|}{$\begin{array}{l}\text { Buying food in } \\
\text { person from a } \\
\text { small supermarket } \\
\text { or grocery store }\end{array}$} \\
\hline $\begin{array}{l}\text { Having meals } \\
\text { delivered directly } \\
\text { to my home from a } \\
\text { full-service or fast } \\
\text { food restaurant or } \\
\text { by a delivery } \\
\text { application }\end{array}$ & & & & & & & \\
\hline
\end{tabular}

11. What has changed in your shopping behavior during the outbreak of COVID-19 and lockdown?

- I go shopping less than usual

- I go shopping like I used to

- I go shopping more than usual

12. What has changed in the extent of your purchase during the outbreak of COVID-19 and lockdown?

- I buy a lot more than usual 
- I buy more than usual

- I buy as same as usual

- I buy less than usual

- I buy a lot less than usual

13. Since the coronavirus (COVID-19) became serious in your country, have you eaten or drunk more or less of the following foods?

\begin{tabular}{|c|c|c|c|c|c|c|c|}
\hline & First Time & $\begin{array}{l}\text { Much } \\
\text { Less }\end{array}$ & $\begin{array}{l}\text { Moderately } \\
\text { Less }\end{array}$ & $\begin{array}{l}\text { About the } \\
\text { Same }\end{array}$ & $\begin{array}{l}\text { Moderately } \\
\text { More }\end{array}$ & $\begin{array}{l}\text { Much } \\
\text { More }\end{array}$ & Never Eat \\
\hline \multicolumn{8}{|l|}{ Fruits/Vegetables } \\
\hline \multicolumn{8}{|l|}{ Meat } \\
\hline \multicolumn{8}{|l|}{ Healthy food } \\
\hline \multicolumn{8}{|l|}{$\begin{array}{l}\text { Unhealthy food } \\
\text { (Fast food) }\end{array}$} \\
\hline \multicolumn{8}{|l|}{ Water } \\
\hline \multicolumn{8}{|l|}{$\begin{array}{c}\text { Candy, Cookies, } \\
\text { cakes, and pastries }\end{array}$} \\
\hline \multicolumn{8}{|l|}{ Healthy Snacks } \\
\hline \multicolumn{8}{|l|}{ Unhealthy snacks } \\
\hline \multicolumn{8}{|l|}{$\begin{array}{l}\text { Packaged frozen } \\
\text { foods }\end{array}$} \\
\hline Canned food & & & & & & & \\
\hline
\end{tabular}

14. Since the coronavirus (COV-19) became serious in your country, have you done more or less of the following food related activities than you used to?

\begin{tabular}{|c|c|c|c|c|c|c|c|}
\hline & First Time & $\begin{array}{l}\text { Much } \\
\text { Less }\end{array}$ & $\begin{array}{l}\text { Moderately } \\
\text { Less }\end{array}$ & $\begin{array}{l}\text { About the } \\
\text { Same }\end{array}$ & $\begin{array}{l}\text { Moderately } \\
\text { More }\end{array}$ & $\begin{array}{l}\text { Much } \\
\text { More }\end{array}$ & $\begin{array}{l}\text { Never } \\
\text { Did }\end{array}$ \\
\hline \multicolumn{8}{|l|}{ Eating at home alone } \\
\hline \multicolumn{8}{|l|}{$\begin{array}{l}\text { Eating with family } \\
\text { members }\end{array}$} \\
\hline \multicolumn{8}{|l|}{$\begin{array}{l}\text { Eating out (e.g., } \\
\text { restau- } \\
\text { rants/cafeteria/fast } \\
\text { food) }\end{array}$} \\
\hline \multicolumn{8}{|l|}{$\begin{array}{l}\text { Eating at someone } \\
\text { else's place (e.g., } \\
\text { family, friends) }\end{array}$} \\
\hline \multicolumn{8}{|l|}{$\begin{array}{l}\text { Ordering take-away } \\
\text { or fast food meals } \\
\text { with deliveries }\end{array}$} \\
\hline \multicolumn{8}{|l|}{$\begin{array}{l}\text { Cooking and } \\
\text { preparing food }\end{array}$} \\
\hline \multicolumn{8}{|l|}{$\begin{array}{l}\text { Spending a lot of } \\
\text { time cooking }\end{array}$} \\
\hline \multicolumn{8}{|l|}{$\begin{array}{l}\text { Making easy meals } \\
\text { (e.g., instant foods, } \\
\text { frozen foods, etc.) }\end{array}$} \\
\hline $\begin{array}{c}\text { Eating between } \\
\text { meals (e.g., snacks) }\end{array}$ & & & & & & & \\
\hline
\end{tabular}

15. Have you stocked up on food and beverages because of the coronavirus (COVID-19)?

- Yes

- $\quad$ No

16. What type of food you stocked up the most during the outbreak of COVID-19 and lockdown? (Please select all that apply) 
- Cereals and their products (bread, rice, pasta, flour, etc.)

- Roots and tubers (potatoes, etc.)

- Legumes (e.g., peas, chickpeas)

- Sugar

- Oil

- $\quad$ Fruits and vegetables

- Meat and meat products

- Fish and seafood

- Milk and dairy products

- Canned food

- None

17. Since the COVID-19 outbreak, did you notice that any of these items is less available? (Please select all that apply)

- Cereals and products (bread, rice, pasta, flour, etc.)

- $\quad$ Roots and tubers (potatoes, etc.)

- Legumes (e.g., peas, chickpeas)

- Sugar

- Oil

- $\quad$ Fruits and vegetables

- Meat and meat products

- $\quad$ Fish and seafood

- Milk and dairy products

- Canned food

- None

18. Since the COVID-19 outbreak, did you notice any price increase for any of these items? (Please select all that apply)

- Cereals and products (bread, rice, pasta, flour, etc.)

- $\quad$ Roots and tubers (potatoes, etc.)

- Legumes (e.g., peas, chickpeas)

- Sugar

- Oil

- $\quad$ Fruits and vegetables

- Meat and meat products

- $\quad$ Fish and seafood

- Milk and dairy products

- Canned food

- None

19. How does stocking up on items make you feel?

\begin{tabular}{lccccc}
\hline & $\begin{array}{c}1 \\
\text { (Not at All) }\end{array}$ & 2 & 3 & 4 & $\begin{array}{c}5 \\
\text { (Very Much) }\end{array}$ \\
\hline Stocking up on items makes me feel less anxious & & & & \\
\hline Stocking up on items makes me feel more secure & & & \\
\hline Stocking up on items comforts me & & \\
\hline Stocking up on items gives me a sense of control & & \\
\hline
\end{tabular}

20. Please indicate how concerned you have been since COVID-19 became serious in your country about the following food-related issues? 


\begin{tabular}{cccccc}
\hline & $\begin{array}{c}1 \\
\text { (Not at All } \\
\text { Concerned) }\end{array}$ & 2 & 3 & 4 & $\begin{array}{c}5 \\
\text { (Extremely } \\
\text { Concerned) }\end{array}$ \\
\hline Obtaining enough food & & & \\
\hline Obtaining a variety of food & & & \\
\hline Access to healthy and safe food & & \\
\hline Food prices rising & \\
\hline Food spreading COVID-19 & \\
\hline
\end{tabular}

21. Regarding changes in your food related behaviors since the outbreak of COVID-19

\begin{tabular}{ccc}
\hline & Yes & No \\
\hline Do you buy more food out of fear or anxiety? & \\
\hline Do you eat more food out of fear, anxiety or boredom? & \\
\hline Are you wasting more food than usual? & \\
\hline Are you more aware of how much food you waste? & \\
\hline
\end{tabular}

22. How has your food wastage changed during the outbreak of COVID-19 and lockdown?

- It has become much less

- Less

- Has not changed

- More

- Much more

\section{Emotions}

23. Please indicate your negative feelings since the onset of COVID-19

\begin{tabular}{ccllll}
\hline & $\mathbf{1}$ (Not at All) & $\mathbf{2}$ & 3 & $\mathbf{5}$ & (Very Much) \\
\hline Nervous & & & & \\
\hline Worried & & & & \\
\hline Depressed & & & \\
\hline Sad & & & \\
\hline Scared & & \\
\hline Bored & & \\
\hline
\end{tabular}

24. Please indicate your positive feelings since the onset of COVID-19

\begin{tabular}{ccccccc}
\hline & $\mathbf{1}$ (Not at All) & $\mathbf{2}$ & 3 & $\mathbf{5}$ & (Very Much) \\
\hline Calm & & & & & \\
\hline Optimistic & & & & & \\
\hline Excited & & & & \\
\hline Happy & & & & \\
\hline
\end{tabular}

\section{References}

1. Mathur, A.; Moschis, G.P.; Lee, E. Life Events and Brand Preference Changes. J. Consum. Behav. 2003, 3, 129-141. [CrossRef]

2. Botti, S.; McGill, A.L. The Locus of Choice: Personal Causality and Satisfaction with Hedonic and Utilitarian Decisions. J. Consum. Res. 2011, 37, 1065-1078. [CrossRef]

3. Hakovirta, M.; Denuwara, N. How COVID-19 Redefines the Concept of Sustainability. Sustainability 2020, 12, 3727. [CrossRef]

4. Calabrese, G.; El Bilali, H.; Raeli, M. Exploring the Nexus Between Pandemics and Natural Capital: COVID-19 and Other Zoonoses. N. Medit. 2020, 4, 145-151.

5. El Bilali, H.; Strassner, C.; Ben Hassen, T. Sustainable Agri-Food Systems: Environment, Economy, Society, and Policy. Sustainability 2021, 13, 6260. [CrossRef] 
6. European Institute of Innovation and Technology. COVID-19 Impact on Consumer Food Behaviours in Europe. Available online: https://www.eitfood.eu/media/news-pdf/COVID-19_Study_-_European_Food_Behaviours_-_Report.pdf (accessed on 11 December 2020).

7. Pérez-Escamilla, R.; Cunningham, K.; Moran, V.H. COVID-19 and Maternal and Child Food and Nutrition Insecurity: A Complex Syndemic. Matern. Child Nutr. 2020, 16, e13036. [CrossRef]

8. Deloitte. How Modernized IT Systems Can Help Businesses Thrive in a Post-Pandemic World. Available online: https://www2 .deloitte.com/content/dam/Deloitte/us/Documents/process-and-operations/us-how-modernized-it-systems-can-help.pdf (accessed on 7 June 2020).

9. Accenture. COVID-19 is Increasing Consumers Focus on Ethical Consumption. 2020. Available online: https://newsroom accenture.com/news/covid-19-increasing-consumers-focus-on-ethical-consumption-accenture-survey-finds.htm (accessed on 10 November 2020).

10. Lazzerini, M.; Putoto, G. COVID-19 in Italy: Momentous Decisions and Many Uncertainties. Lancet Glob. Health 2020, 8, e641-e642. [CrossRef]

11. Ahmed, S.; Downs, S.M.; Yang, C.; Chunlin, L.; Broek, N.T.; Ghosh-Jerath, S. Rapid Tool Based on a Food Environment Typology Framework for Evaluating Effects of the COVID-19 Pandemic on Food System Resilience. Food Secur. 2020, 12, 773-778. [CrossRef]

12. Akter, S. The Impact Of COVID-19 Related 'Stay-At-Home' Restrictions on Food Prices in Europe: Findings from a Preliminary Analysis. Food Secur. 2020, 12, 719-725. [CrossRef] [PubMed]

13. Ben Hassen, T.; El Bilali, H.; Allahyari, M.S.; Charbel, L. Food Shopping, Preparation and Consumption Practices in Times of COVID-19: Case of Lebanon. J. Agribus. Dev. Emerg. Econ. 2021, ahead of print. [CrossRef]

14. El Bilali, H.; Ben Hassen, T.; Chatti, C.B.; Abouabdillah, A.; Alaoui, S.B. Exploring Household Food Dynamics During the COVID-19 Pandemic in Morocco. Front. Nutr. 2021, 8. [CrossRef]

15. Hall, C.; Fieger, P.; Prayag, G.; Dyason, D. Panic Buying and Consumption Displacement during COVID-19: Evidence from New Zealand. Economies 2021, 9, 46. [CrossRef]

16. Gutiérrez-Villar, B.; Melero-Bolaños, R.; Carbonero-Ruz, M. COVID-19's First Wave: Examination of Impact on Food Purchasing Behaviour in the Eurozone. Foods 2021, 10, 1179. [CrossRef]

17. Cranfield, J.A.L. Framing Consumer Food Demand Responses in a Viral Pandemic. Can. J. Agric. Econ. 2020, 68, 151-156. [CrossRef]

18. Wesseler, J. Storage Policies: Stockpiling Versus Immediate Release. J. Agric. Food Ind. Organ. 2019, 18. [CrossRef]

19. Nicola, M.; Alsafi, Z.; Sohrabi, C.; Kerwan, A.; Al-Jabir, A.; Iosifidis, C.; Agha, M.; Agha, R. The Socio-Economic Implications of the Coronavirus Pandemic (COVID-19): A Review. Int. J. Surg. 2020, 78, 185-193. [CrossRef]

20. WHO Food and Nutrition Tips During Self-Quarantine. Available online: https://www.euro.who.int/en/health-topics/ health-emergencies / coronavirus-covid-19/technical-guidance/food-and-nutrition-tips-during-self-quarantine (accessed on 4 September 2020).

21. Wang, E.; An, N.; Gao, Z.; Kiprop, E.; Geng, X. Consumer Food Stockpiling Behavior and Willingness to Pay for Food Reserves In COVID-19. Food Secur. 2020, 12, 739-747. [CrossRef]

22. WHO Serbia. WHO Coronavirus Disease (COVID-19) Dashboard. Available online: https://covid19.who.int/region/euro/ country / rs (accessed on 16 May 2021).

23. The Government of the Republic of Serbia. First Case of Coronavirus in Serbia Confirmed. Available online: https://www.srbija. gov.rs /vest/en/150981/ first-case-of-coronavirus-in-serbia-confirmed.php (accessed on 27 February 2021).

24. Šantić, D.; Antić, M. Serbia in the Time of COVID-19: Between "Corona Diplomacy", Tough Measures and Migration Management. Eurasian Geogr. Econ. 2020, 61, 546-558. [CrossRef]

25. Öcal, A.; Cvetković, V.M.; Baytiyeh, H.; Tedim, F.M.S.; Zečević, M. Public Reactions to the Disaster COVID-19: A Comparative Study in Italy, Lebanon, Portugal, and Serbia. Geomatics. Nat. Hazards Risk 2020, 11, 1864-1885. [CrossRef]

26. Marinković, V.; Lazarević, J. Eating Habits and Consumer Food Shopping Behaviour during COVID-19 Virus Pandemic: Insights from Serbia. Br. Food J. 2021. ahead of print. [CrossRef]

27. Danas Panic Buying Makes Serbians Spend More on Grocery, Household Goods. Available online: https://www.danas.rs/ drustvo/zbog-panike-domacinstva-u-srbiji-potrosila-dve-milijarde-dinara-vise/ (accessed on 30 May 2021).

28. Berjan, S.; Vaško, Ž.; Ben Hassen, T.; El Bilali, H.; Allahyari, M.S.; Tomić, V.; Radosavac, A. Assessment of Household Food Waste Management During the COVID-19 Pandemic in Serbia: A Cross-Sectional Online Survey. Environ. Sci. Pollut. Res. 2021, 1-12. [CrossRef]

29. Đuričin, S.; Antonijević, M. The Role of Online Shopping in the Republic of Serbia During COVID-19. Econ. Anal. 2020, 53.

30. Colafemmina, D.; El Bilali, H.; Capone, R. Impacts of COVID-19 on Food Security and Food System Sustainability. In Proceedings of the XI International Scientific Agriculture Symposium “Agrosym 2020", Sarajevo, Bosnia and Herzegovina, 8-9 October 2020; pp. 925-933.

31. Arafat, S.M.Y.; Kar, S.K.; Menon, V.; Kaliamoorthy, C.; Mukherjee, S.; Alradie-Mohamed, A.; Sharma, P.; Marthoenis, M.; Kabir, R. Panic Buying: An Insight from The Content Analysis of Media Reports during COVID-19 Pandemic. Neurol. Psychiatry Brain Res. 2020, 37, 100-103. [CrossRef] [PubMed]

32. Somani, A.; Kumar, A. Historical Perspectives of Panic Buying. In Panic Buying; Arafat, S.Y., Kumar, K.S., Kabir, R., Eds.; Springer: Cham, Switzerland, 2021; pp. 115-123. 
33. Pantano, E.; Pizzi, G.; Scarpi, D.; Dennis, C. Competing During a Pandemic? Retailers' Ups and Downs During the COVID-19 Outbreak. J. Bus. Res. 2020, 116, 209-213. [CrossRef] [PubMed]

34. Cooper, M.A.; Gordon, J.L. Understanding Panic Buying Through an Integrated Psychodynamic Lens. Front. Public Health 2021, 9, 666715. [CrossRef] [PubMed]

35. Fortin, D.; Uncles, M. The First Decade: Emerging Issues of the Twenty-First Century in Consumer Marketing. J. Consum. Mark. 2011, 28, 472-475. [CrossRef]

36. Loxton, M.; Truskett, R.; Scarf, B.; Sindone, L.; Baldry, G.; Zhao, Y. Consumer Behaviour during Crises: Preliminary Research on How Coronavirus has Manifested Consumer Panic Buying, Herd Mentality, Changing Discretionary Spending and the Role of the Media in Influencing Behaviour. J. Risk Financial Manag. 2020, 13, 166. [CrossRef]

37. Lehberger, M.; Kleih, A.-K.; Sparke, K. Panic Buying in Times of Coronavirus (COVID-19): Extending the Theory of Planned Behavior to Understand the Stockpiling of Nonperishable Food in Germany. Appetite 2021, 161, 105118. [CrossRef] [PubMed]

38. Messner, W.; Payson, S.E. Effects of National Culture on the Extent of Panic Buying during the COVID-19 Outbreak. J. Int. Consum. Mark. 2021, 1-20. [CrossRef]

39. Tsao, Y.-C.; Raj, P.V.R.P.; Yu, V. Product Substitution in Different Weights and Brands Considering Customer Segmentation and Panic Buying Behavior. Ind. Mark. Manag. 2019, 77, 209-220. [CrossRef]

40. Chen, C.Y.; Lee, L.; Yap, A.J. Control Deprivation Motivates Acquisition of Utilitarian Products. J. Consum. Res. 2017, 43, 1031-1047. [CrossRef]

41. Keane, M.; Neal, T. Consumer Panic in the COVID-19 Pandemic. J. Econ. 2021, 220, 86-105. [CrossRef] [PubMed]

42. Kemp, E.; Kennett-Hensel, P.A.; Williams, K.H. The Calm before the Storm: Examining Emotion Regulation Consumption in the Face of an Impending Disaster. Psychol. Mark. 2014, 31, 933-945. [CrossRef]

43. Larson, L.R.L.; Shin, H. Fear During Natural Disaster: Its Impact on Perceptions of Shopping Convenience and Shopping Behavior. Serv. Mark. Q. 2018, 39, 293-309. [CrossRef]

44. Beard-Knowland, T. The Impact of COVID-19 On How We Eat. Available online: https:/ /www.ipsos.com/sites/default/files / ct/publication/documents/2020-05/impact_of_covid-19_on_how_we_eat_ipsos_sia.pdf (accessed on 5 June 2020).

45. EY Four Consumer Behavior Trends Emerge During the COVID-19 Pandemic, the First EY Future Consumer Index Finds. Available online: https://www.ey.com/en_gl/news/2020/04/four-consumer-behavior-trends-emerge-during-the-covid-19 -pandemic-the-first-ey-future-consumer-index-finds (accessed on 10 November 2020).

46. Sheu, J.-B.; Kuo, H.-T. Dual Speculative Hoarding: A Wholesaler-Retailer Channel Behavioral Phenomenon Behind Potential Natural Hazard Threats. Int. J. Disaster Risk Reduct. 2020, 44, 101430. [CrossRef]

47. Yuen, K.F.; Wang, X.; Ma, F.; Li, K.X. The Psychological Causes of Panic Buying Following a Health Crisis. Int. J. Environ. Res. Public Heal. 2020, 17, 3513. [CrossRef]

48. Martin-Neuninger, R.; Ruby, M.B. What Does Food Retail Research Tell Us about the Implications of Coronavirus (COVID-19) for Grocery Purchasing Habits? Front. Psychol. 2020, 11. [CrossRef]

49. McKinsey. Redefining Value and Affordability in the Retail Sector's Next Normal. Available online: https://www.mckinsey. $\mathrm{com} /$ industries / retail/our-insights/redefining-value-and-affordability-in-retails-next-normal (accessed on 10 September 2020).

50. Maghsoudi, A.; Zailani, S.; Ramayah, T.; Pazirandeh, A. Coordination of Efforts in Disaster Relief Supply Chains: The Moderating Role of Resource Scarcity and Redundancy. Int. J. Logist. Res. Appl. 2018, 21, 407-430. [CrossRef]

51. Sterman, J.D.; Dogan, G. "I'm Not Hoarding, I'm just Stocking Up before the Hoarders Get Here.": Behavioral Causes of Phantom Ordering in Supply Chains. J. Oper. Manag. 2015, 39-40, 6-22. [CrossRef]

52. Grasso, S. Consequences of Panic Buying-IFNH. Available online: https://research.reading.ac.uk/ifnh/2020/04/20 / consequences-of-panic-buying/ (accessed on 5 June 2020).

53. Naeem, M. Do Social Media Platforms Develop Consumer Panic Buying During the Fear of Covid-19 Pandemic. J. Retail. Consum. Serv. 2021, 58, 102226. [CrossRef]

54. Kirk, C.P.; Rifkin, L.S. I'll Trade You Diamonds for Toilet Paper: Consumer Reacting, Coping and Adapting Behaviors in the COVID-19 Pandemic. J. Bus. Res. 2020, 117, 124-131. [CrossRef] [PubMed]

55. Hesham, F.; Riadh, H.; Sihem, N.K. What Have We Learned about the Effects of the COVID-19 Pandemic on Consumer Behavior? Sustainability 2021, 13, 4304. [CrossRef]

56. Naja, F; Hamadeh, R. Nutrition Amid the COVID-19 Pandemic: A Multi-Level Framework for Action. Eur. J. Clin. Nutr. 2020, 74, 1117-1121. [CrossRef]

57. Prentice, C.; Chen, J.; Stantic, B. Timed Intervention in COVID-19 and Panic Buying. J. Retail. Consum. Serv. 2020, 57, 102203. [CrossRef]

58. Wang, H.H.; Hao, N. Panic Buying? Food Hoarding During the Pandemic Period with City Lockdown. J. Integr. Agric. 2021, 19, 2916-2925. [CrossRef]

59. Jribi, S.; Ben Ismail, H.; Doggui, D.; Debbabi, H. COVID-19 Virus Outbreak Lockdown: What Impacts on Household Food Wastage? Environ. Dev. Sustain. 2020, 22, 3939-3955. [CrossRef]

60. Zheng, R.; Shou, B.; Yang, J. Supply Disruption Management under Consumer Panic Buying and Social Learning Effects. Omega 2021, 101, 102238. [CrossRef] 
61. Mussell, A.; Bilyea, T.; Hedley, D. Agri-Food Supply Chains and Covid-19: Balancing Resilience and Vulnerability; 2020. Available online: http: / / www.agrifoodecon.ca/uploads / userfiles / files/agri-food\%20supply\%20chains \%20and \%20covid-19\%20mar\% 2022-20.pdf (accessed on 14 July 2020).

62. Eger, L.; Komárková, L.; Egerová, D.; Mičík, M. The Effect of COVID-19 on Consumer Shopping Behaviour: Generational Cohort Perspective. J. Retail. Consum. Serv. 2021, 61, 102542. [CrossRef]

63. Parker, C.; Scott, S.; Geddes, A. Snowball Sampling. In SAGE Research Methods Foundations; SAGE Publications Ltd.: London, UK, 2019.

64. Marcus, B.; Weigelt, O.; Hergert, J.; Gurt, J.; Gelléri, P. The Use of Snowball Sampling for Multi Source Organizational Research: Some Cause for Concern. Pers. Psychol. 2017, 70, 635-673. [CrossRef]

65. Western Michigan University (WMU). Researchers Study Food Consumption Behavior during COVID-19 Pandemic. Available online: https: / /wmich.edu/news/2020/03/58581 (accessed on 14 July 2020).

66. UNSCN. UNSCN COVID-19 Questionnaire. Available online: https://www.unscn.org/en/news-events/recent-news?idnews= 2045 (accessed on 24 July 2020).

67. Ben Hassen, T.; El Bilali, H.; Allahyari, M.S. Impact of COVID-19 on Food Behavior and Consumption in Qatar. Sustainability 2020, 12, 6973. [CrossRef]

68. Ben Hassen, T.; El Bilali, H.; Allahyari, M.S.; Berjan, S.; Fotina, O. Food Purchase and Eating Behavior During the COVID-19 Pandemic: A Cross-Sectional Survey of Russian Adults. Appetite 2021, 165, 105309. [CrossRef] [PubMed]

69. Ben Hassen, T.; El Bilali, H.; Allahyari, M.S.; Karabašević, D.; Radosavac, A.; Berjan, S.; Vaško, Ž.; Radanov, P.; Obhođaš, I. Food Behavior Changes during the COVID-19 Pandemic: Statistical Analysis of Consumer Survey Data from Bosnia and Herzegovina. Sustainability 2021, 13, 8617. [CrossRef]

70. Rossolov, A.; Kuzkin, O.; Rossolova, H. Emergency Supplies Purchase Patterns During COVID-19 Outbreak in the Developing Economy: Frequency and Stockpiling Drivers' Assessment. J. Humanit. Logist. Supply Chain Manag. 2021, ahead of print. [CrossRef]

71. Hansman, C.; Hong, H.; de Paula, Á.; Singh, V. A Sticky-Price View of Hoarding. Available online: http:/ / www.nber.org/papers / w27051 (accessed on 31 May 2021).

72. Yildirim, H.; Capone, R.; Karanlik, A.; Bottalico, F.; Debs, P.; El Bilali, H. Food Wastage in Turkey: An Exploratory Survey on Household Food Waste. J. Food Nutr. Res. 2016, 4, 483-489.

73. Berjan, S.; Mrdalj, V.; EL Bilali, H.; Velimirovic, A.; Blagojevic, Z.; Bottalico, F.; Debs, P.; Capone, R. Household Food Waste in Montenegro. Ital. J. Food Sci. 2019, 31, 274-287. [CrossRef]

74. Bogevska, Z.; Berjan, S.; Capone, R.; Debs, P.; El Bilali, H.; Bottalico, F.; Davitkovska, M. Household Food Wastage in North Macedonia. J. Agric. For. 2020, 66. [CrossRef]

75. National Geographic Serbia. How Much (Really) Do We Throw Away Food? Available online: https:/ / www.nationalgeographic. rs/vesti/14153-koliko-zaista-bacamo-hranu.html (accessed on 16 May 2021).

76. Djekic, I.; Miloradovic, Z.; Djekic, S.; Tomasevic, I. Household Food Waste in Serbia-Attitudes, Quantities and Global Warming Potential. J. Clean. Prod. 2019, 229, 44-52. [CrossRef]

77. Principato, L.; Secondi, L.; Cicatiello, C.; Mattia, G. Caring More About Food: The Unexpected Positive Effect of the Covid-19 Lockdown on Household Food Management and Waste. Socio-Econ. Plan. Sci. 2020, 100953. [CrossRef]

78. Georgiadou, E.; Koopmann, A.; Müller, A.; Leménager, T.; Hillemacher, T.; Kiefer, F. Who Was Shopping More During the Spring Lockdown 2020 in Germany? Front. Psychiatry 2021, 12. [CrossRef]

79. Ogundijo, D.; Tas, A.; Onarinde, B. Exploring the Impact of COVID-19 Pandemic on Eating and Purchasing Behaviours of People Living in England. Nutrients 2021, 13, 1499. [CrossRef]

80. Borsellino, V.; Kaliji, S.; Schimmenti, E. COVID-19 Drives Consumer Behaviour and Agro-Food Markets towards Healthier and More Sustainable Patterns. Sustainability 2021, 12, 8366. [CrossRef]

81. Cox, A.D.; Cox, D.; Anderson, R.D. Reassessing the Pleasures of Store Shopping. J. Bus. Res. 2005, 58, 250-259. [CrossRef]

82. Phua, P.; Kennedy, R.; Trinh, G.; Page, B.; Hartnett, N. Examining Older Consumers' Loyalty Towards Older Brands in Grocery Retailing. J. Retail. Consum. Serv. 2020, 52, 101893. [CrossRef]

83. Al Jazeera. Panic Buying in Taiwan as New COVID-19 Rules Kick Off. Available online: https://www.aljazeera.com/news/2021 /5/16/taiwan-urges-no-panic-buying-as-new-covid-19-rules-kick-off (accessed on 30 May 2021).

84. Roy, D.; Tripathy, S.; Kar, S.K.; Sharma, N.; Verma, S.K.; Kaushal, V. Study of Knowledge, Attitude, Anxiety \& Perceived Mental Healthcare Need in Indian Population During COVID-19 Pandemic. Asian J. Psychiatr. 2020, 51, 102083. [PubMed]

85. Monzon, A.; Bayart, C. Workshop Synthesis: Web-Based Surveys, New Insight to Address Main Challenges. Transp. Res. Procedia 2018, 32, 167-173. [CrossRef]

86. Couper, M.P. Web Surveys. Public Opin. Q. 2000, 64, 464-494. [CrossRef] [PubMed]

87. Lehdonvirta, V.; Oksanen, A.; Räsänen, P.; Blank, G. Social Media, Web, and Panel Surveys: Using Non-Probability Samples in Social and Policy Research. Policy Internet 2021, 13, 134-155. [CrossRef] 